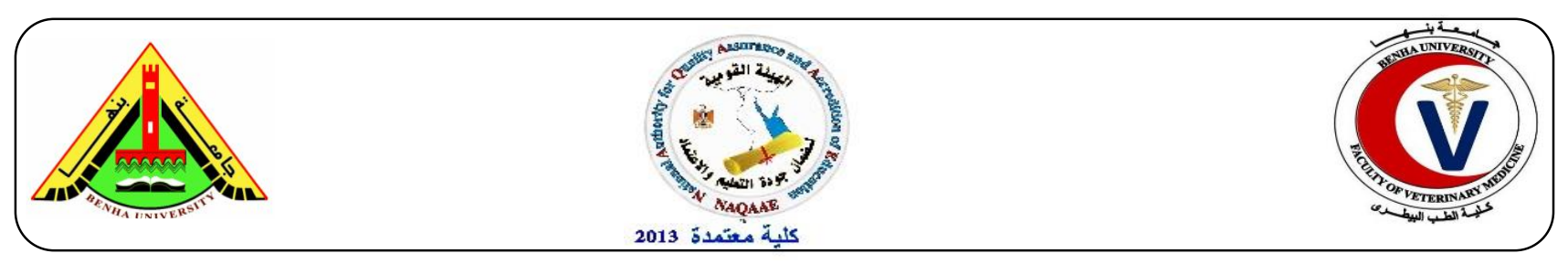

\title{
Evaluation of the Quality of the Minced Meat in Egyptian Markets
}

\author{
Saad M.S. ${ }^{1}$; Hassan M.A. ${ }^{1}$; Zaghloul M. N; and Elgnainy N. F³. \\ ${ }^{1}$ Food Hyigene and Control Dep., Fac. Vet. Med., Benha univ. \\ ${ }^{2}$ Meat hygiene, animal research institute Banha Branch. \\ ${ }^{3}$ Veterinary practitioner.
}

\begin{abstract}
A B S T R A C T
The aim of the present study is to evaluate the quality of minced meat (fresh - frozen) in Egyptian markets. A total of 90 minced meat samples ( 45 fresh -45 frozen) were collected from butchers and retailed supermarkets shops in different locations in Egypt.All collected samples were transferred directly to the laboratory in an ice box under complete aseptic conditions without any delay and then subjected to bacteriological examination to evaluate the quality of minced meat based on their contamination with coliform and staphylococcus spp. The obtained results indicated that the mean value of staphylococcal count and coliform count of the examined fresh minced meat samples were $26.0 \pm 2.2 \times 10^{2} \mathrm{cfu} / \mathrm{g}$ and $19.0 \pm 0.8 \times 10^{3} \mathrm{cfu} / \mathrm{g}$, respectively, while of the frozen minced meat samples were $8.8 \pm 0.7 \times 10^{2} \mathrm{cfu} / \mathrm{g}$, and $14.8 \pm 0.5 \times 10^{3} \mathrm{cfu} / \mathrm{g}$ respectively. $100 \%$ of the examined fresh minced meat samples (45 samples) were unaccepted samples and $33.3 \%$ of the examined samples identified as Staph. Aureus and $28.9 \%$ of the examined frozen minced meat samples (13 samples) were unaccepted samples and 23.1\% identified as Staph. Aureus according to EOS 1694 / $2005\left(10^{2} \mathrm{cfu} / \mathrm{g}\right)$. Accepted samples based on their coliforms count were $68.8 \%$ and $88.8 \%$ for fresh and frozen samples, respectively according to EOS (1694/2005). These results indicated that the microbiological quality of retailed minced meat samples were unsatisfactory, and have health hazards for consumers as it may be lead to food poisoning.
\end{abstract}

Key words: Fresh Meat, Frozen meat, coliform, Staphylococcal.

(http://www.bvmj.bu.edu.eg)

(BVMJ-35(2): 249-256, 2018)

\section{INTRODUCTION}

People depending on the meat as daily food worldwide because of its high protein content. Protein of the meat consists of essential amino acids that have been considered as good source for the human body needed (Olaoye, 2011).

Moreover, meat contain high level of water corresponding to the water activity of approximately 0.99 , which is suitable for the growth of different types of microorganisms (Rao et al.,2009).

In the last few years, there were a huge increase in the consumption of processed meat worldwide because of their convenience to consumer and their nutritive values (Rajic'et al., 2007).

On the other hand, meat products are a major source of diseases especially foodborne 
diseases and related to worldwide out breaks resulting from food poisoning .For that reason, food poisoning bacteria especially Salmonella organisms which cause meat products contamination (Amin-Reham, 2004 and Erdem et al., 2005).

Hence, meat become unfit for human consumption when subjected to spoilage and its enzymatic changes, microbial action and any other factors (Bradeeba and Sivakumaar, 2013).

Likewise, ground meat enter mainly in most types of meat products meals as a source of food animal origin, so it has high economic value because of its nutritive quality but also, ground meat highly subjected to food poisoning resulting from microbial contamination (Velzen et al., 2008).

Also, ground meat is not only highly susceptible to spoilage, but also is frequently involved in the spread of pathogens (Ahmed and Ismail, 2010).

Besides, studies on the microbiological quality of food, ground meat considered a good medium for the growth of the pathogenic microorganisms as the minced meat rich in nutrients required for this growth (Elmali and Yaman 2005 and Norman et al., 2006). In addition, high incidence of illness and death worldwide resulting from spoilage of the meat (Adak et al., 2005). It is due to consumption of bacteria, toxins and cells produced by pathogenic microorganisms present in food (Clarince et al. 2009).

On the other context, minced meat may be polluted with biological agents during production, processing, storage and marketing that may be serious to human health (Siriken, 2004), accordingly high levels of microorganisms including pathogens means low meat quality depending on the hygienic measures of meat processing (Tachbele et al., 2006). Determination of enterobacteriaceae considered as the main element in quality judgement of slaughter hygiene and slaughter
- houses (Zweifel et al, 2008). Moreover, The Staph. Aureus is ubiquitous in nature and inhabits the mucous membranes and skin of most warm-blooded animal including food animals and humans. Up to $50 \%$ of humans may carry this organism in their nose and throats and on hair and skin (USFDA, 2004). Furthermore, Salmonella is the second popular cause of illness. millions cases of food borne diseases recorded every year (HGIC, 2000). In conclusion, the recorded data from several European countries show that the incidence of salmonella in minced meat beef ranged from $0.0 \%$ to $3.6 \%$, with a mean of 1.1\% (Anon, 2006). Also, in Egypt the incidence of salmonella reached $20 \%$ of frozen meat beef samples (Hassanin et al. 2011).

In addition, the $E$. coli is the most common cause to infants, children diarrhea cases, many species as (buffalo, cows and sheep) were the highest reservoir of $E$. coli infection to man (Taha, 2002). Recognizing this, the World Health Organization developed its Global Strategy for Food Safety. So, The microbiological safety of food is occurred by absence of pathogenic microorganisms and by applying measures for preventing their multiplication (Omemu and Bankole 2005).

Furthermore, the food safety measures should be done perfectly in application of HACCP (Hazard analysis critical control point), for reducing the food-borne illnesses and to maintain the level of microbial load of raw meat in check, but in developing countries, the bad sanitary level during transportation and storage conditions not only the cause of contamination but also enhance the growth of pathogenic bacteria in meat in addition to different types of spoilage (Javed, 2016).

\section{MATERIALS AND METHODS}

2.1. Collection of samples: 
A grand total of 90 random minced meat samples classified into fresh and frozen (45 Of each) were collected from local supermarkets and retail shops from different locations all over the country. The collected samples were transferred directly to the laboratory in an ice box under complete aseptic conditions without any delay and then subjected to following examination to evaluate chemical and bacteriological quality after thawing in the refrigerator overnight.

2.2. Preparation of samples (ISO, 2003):

2.3. Determination of Total coliforms count (ISO, 2004):

2.4. Determination of Total staphylococcal count and Isolation of staphylococcus aureus (FDA, 2001)

2.5. Identification of suspected Staph. aureus

Morphological identification: ( Cruickshank et al , 1975)

Gram staining:

Motility test:

Biochemical identification: (FDA , 2001)

Detection of haemolysis:

Indole test:

Methyl red test:

Catalase test:

Oxidase test:

Sugar fermentation test:

Coagulase test (Tube coagulase test):

\section{RESULTS}

3.1. Total Staphylococcal counts (cfu/g) of the examined fresh and frozen minced meat samples:

in the present study, it is evident from the results recorded in Table (1) that total staphylococcal count of the examined fresh minced was ranged from $11 \times 10^{3}$ to $41 \times$ $10^{3} \mathrm{cfu} / \mathrm{g}$, with a mean value of $26.0 \pm 2.2 \times$ $10^{3} \mathrm{cfu} / \mathrm{g}$ while of the frozen minced meat samples was ranged from $4.6 \times 10^{3}$ to $13 \times$
$10^{3} \mathrm{cfu} / \mathrm{g}$ with a mean value of $8.8 \pm$ $0.7 \times 10^{3} \mathrm{cfu} / \mathrm{g}$.

table (2) show that $100 \%$ of the examined fresh minced meat samples (45 samples) were unaccepted samples and 28.9 $\%$ of the examined frozen minced meat samples (13 samples) were unaccepted samples but $71.1 \%$ were accepted (32 samples) based on their staphylococcal count. There is a Significant difference between the examined frozen and fresh minced meat samples $(\mathrm{P}>0.05)$.

3.2. The incidence of Staph. aureus (cfu/g) of the examined fresh and frozen minced meat samples:

The results recorded in Table (3) revealed that unaccepted samples for Staph. aureus of the examined fresh and frozen minced meat samples (45 for each) were 15 and 3 samples, respectively.

Table (3) decleared the acceptability of the examined samples of fresh and frozen minced meat samples based on the incidence of Staph. Aureus shown that $33.3 \%$ of the examined fresh minced meat samples (15 samples) were unaccepted samples (exceeded the permissible limits $\left(10^{2} / \mathrm{g}\right)$ according to EOS (2005)) but $66.6 \%$ of were accepted (30 samples) and $6.6 \%$ of the examined frozen minced meat samples (3 samples) were unaccepted samples (exceeded the permissible limits $\left(10^{2} / \mathrm{g}\right)$ according to EOS (2005)) but $93.3 \%$ were accepted (42 samples).

3.3. Total Coliforms count $(\mathrm{cfu} / \mathrm{g})$ of the examined fresh and frozen minced meat samples:

Results achieved in table (4) revealed that coliforms count of the examined fresh minced was ranged from $16 \times 10^{3}$ to $22 \times 10^{3}$ $\mathrm{cfu} / \mathrm{g}$, with a mean value of $19.0 \pm 0.8 \times$ $10^{3} \mathrm{cfu} / \mathrm{g}$ while of the frozen minced meat samples were ranged from $9.5 \times 10^{3}$ to $20 \times$ 
$10^{3} \mathrm{cfu} / \mathrm{g}$ with a mean value of $14.8 \pm 0.5$ $\times 10^{3} \mathrm{cfu} / \mathrm{g}$.

Table (5) and fig (5) decleared the acceptability of the examined samples of fresh and frozen minced meat samples based on their coliforms count shown that $31.1 \%$ of the examined fresh minced meat samples (14 samples) were unaccepted samples but $68.8 \%$ were accepted (31 samples) and $11.1 \%$ of the examined frozen minced meat samples (5 samples) were unaccepted samples but $88.8 \%$ were accepted (40 samples).

Table (1) statistical analytical results of staphylococcal count (cfu/g) in the examined fresh and frozen minced meat samples $\left(n=45\right.$ for each $\left.\times 10^{3}\right)$.

Mince Meat samples Min. Max. Mean \pm S.E*

$\begin{array}{lccc}\text { Fresh } & 11 & 41 & 26.0 \pm 2.2 \\ \text { Frozen } & 4.6 & 13 & 8.8 \pm 0.7\end{array}$

*SEM $=$ Standard error of mean.

N.B: Significant difference $(P<0.05)$.

Table (2) acceptability of the examined fresh and frozen minced meat samples based on their Staphylococcal count $(n=45)$.

\begin{tabular}{cccccccc}
\hline $\begin{array}{c}\text { Minced meat } \\
\text { samples }\end{array}$ & \multicolumn{2}{c}{ +ve samples } & MPL & \multicolumn{2}{c}{ accepted samples } & \multicolumn{2}{c}{ Unaccepted } \\
samples \\
& No & $\%$ & & No & $\%$ & No & $\%$ \\
\hline fresh & 15 & $100 \%$ & $10^{2}$ & - & - & 45 & $100 \%$ \\
frozen & 13 & $28.9 \%$ & $10^{2}$ & 32 & $71.1 \%$ & 13 & $28.9 \%$ \\
\hline
\end{tabular}

${ }^{2}$ MPL $=$ Maximum permissible limit according to EOS (1694/2005).

Table (3) acceptability of the examined fresh and frozen minced meat samples based on their Staph. Aureus count $(n=45)$.

\begin{tabular}{cccccccc}
\hline $\begin{array}{c}\text { Minced meat } \\
\text { samples }\end{array}$ & \multicolumn{2}{c}{ +ve samples } & MPL & \multicolumn{2}{c}{ accepted samples } & \multicolumn{2}{c}{ Unaccepted } \\
samples \\
& No & $\%$ & & No & $\%$ & No & $\%$ \\
\hline fresh & 15 & $33.3 \%$ & free & 30 & $66.7 \%$ & 15 & $33.3 \%$ \\
frozen & 3 & $23.1 \%$ & free & 10 & $76.9 \%$ & 3 & $23.1 \%$ \\
\hline
\end{tabular}

${ }^{2}$ MPL $=$ Maximum permissible limit according to EOS (1694/ 2005) 
Table (4) statistical analytical results of coliforms count $(\mathrm{cfu} / \mathrm{g})$ in the examined fresh and frozen minced meat samples $(n=45$ for each $\times 103)$.

\begin{tabular}{cccc}
\hline Mince Meat samples & Min. & Max. & Mean \pm S.E* \\
\hline Fresh & 16 & 22 & $19.0 \pm 0.8$ \\
frozen & 9.5 & 20 & $14.8 \pm 0.5$ \\
\hline
\end{tabular}

$* \mathrm{~S} . \overline{\mathrm{E}}=$ Standard error of mean.

N.B: Significant difference $((P<0.05)$.

Table (5) acceptability of the examined fresh and frozen minced meat samples based on their coliforms count $(n=45)$.

\begin{tabular}{cccccccc}
\hline $\begin{array}{c}\text { Minced meat } \\
\text { samples }\end{array}$ & \multicolumn{2}{c}{ +ve samples } & MPL & \multicolumn{2}{c}{ accepted samples } & \multicolumn{2}{c}{ Unaccepted } \\
samples
\end{tabular}

$2 \overline{\mathrm{MPL}}=$ Maximum permissible limit according to EOS (1694/ 2005).

\section{DISCUSSION}

Total Staphylococcal counts (cfu/g) of the examined fresh and frozen minced meat samples:

these high results due to bad handling of the meat, Staph SPP. Present on human hands, nasal passages or throats. accumulation of bacteria on meat handlers lead to production of heat stable toxins in the meat as recorded in table (1) .

These results obtained in table (1) are nearly similar to results obtained by Datta et al., (2012). However higher findings were obtained by Al kour (2001) who found that the mean value of staphylococcal count were $4.13 \times 10^{3} \pm 1.25 \times 10^{3} \mathrm{cfu} / \mathrm{g}$, El Taher Amna (2009) who reported that the mean value of staphylococcal count were $4.16 \times$ $10^{3} \mathrm{cfu} / \mathrm{g}$, Goja et al., (2013) who found that the staphylococcal count ranged from $3.23 \times$ $10^{3}$ to $8.7 \times 10^{3} \mathrm{cfu} / \mathrm{g}$.

While lower results obtained by Bouzid et al., (2015) who found that the incidence of Staphylococcus in examined samples were $4.45 \%$, Guemour et al., (2015) who found that the incidence of Staphylococcus in examined samples were $4.45 \%$. Shaltoot et al., (2016) who recorded that the incidence of presence of staphylococcal count was low.

Staphylococcal food poisoning is a food borne intoxications that develops in people who ingest food that has been improperly prepared or stored. The severity of illness depends on the amount of food ingested, the amount of toxin in ingested food and the general health of the victim (Schelin et al., 2011).

Patients become symptomatic within 2-4hrs. after ingestion of thermostable staphylococcal enterotoxins of an approximate dose of 0.1 to $1.0 \mathrm{mg} / \mathrm{kg}$ of body weight (Stewart et al., 2005). 
The incidence of Staph. aureus (cfu/g) of the examined fresh and frozen minced meat samples:

Staph. Aureus is one of the most important food poisoning micro - organisms (Naomi and Avraham , 2000) This organism is of major concern to the meat industries (Hannan et al , 2008).

This higher results may be due to contamination during processing from the hands, worker's clothes, knives, the hide, the gut or from the environment resulting in an inferior or even unfit quality for human consumption. Or due to ignorance of workers and butchers by the personal hygiene rules. Moreover, a condition like injured hands or having abscess greatly enhance Staph. aureus contamination. Staph. aureus can be isolated from meat grinders, knives, saw blades and cutting boards or tables Downes and Ito (2001).

Table (3) show Nearly similar results obtained by Maarouf and Nassif (2008) the incidence of Staph. aureus were $35.4 \%$, Tassew et al., (2010) who found that the incidence of Staph. aureus were $12.1 \%$, Lamada et al., (2012) who found that the incidence of Staph. aureus were $35.4 \%$ in examined samples. Morshedy et al., (2013) who mentioned that the mean value of Staph. aureus were $4.3 \times 10^{2} \mathrm{cfu} / \mathrm{g}$. Abdel Salam et al., (2014) who recorded that the incidence of Staph. aureus was $35.4 \%$, Bughti et al., (2017) Staph. aureus detected in the examined samples.

However higher findings were obtained by Salek (2000) who found that 28 out of 61 samples were Staph. aureus, Naka et al., (2006) who reported that the incidence of Staph. aureus were $65 \%$ in examined minced meat, Erdema-Ayten et al., (2014) who found that high incidence of Staph. aureus $96.6 \%$ with the mean value was $3.7 \times$
$10^{6} \mathrm{cfu} / \mathrm{g}$, Gwida et al., (2014) who recorded high incidence of Staph. aureus 48\%, Ragab et al., (2016) the mean value of Staph. aureus were $3 \times 10^{3} \mathrm{cfu} / \mathrm{g}$. Mohamed and Alwan (2017) who detected Staph. aureus in 64\% from frozen samples and $50 \%$ from fresh samples.

While lower results obtained by $\mathrm{El}$ Taher - Amna (2009) and Goja et al., (2013) who isolated staph. aureus from the examined samples. Attalla and Kassem (2011) who recorded that the mean value of staph. aureus count were $3.94 \pm 0.16 \log _{10}$. Iraha et al (2011) who recorded that the incidence of Staph. aureus was $1.3 \%$, El Kewaiky and Al Said (2015) who found that the mean value of Staph. aureus were $5.26 \pm 4.7 \log 10$ in examined fresh samples and $4.4 \pm 3.88 \log 10$ in frozen samples. Tarabees et al., (2015) the incidence of Staph. aureus were $20 \%$ in examined samples. Shaltoot et al (2016) the incidence of Staph, aureus was low and the mean value was $2.2 \pm 0.07 \log 10$ in examined samples, Azage and Kibret (2017) who found that the mean value of Staph. aureus $3.88 \log _{10} \mathrm{cfu} / \mathrm{g}$.

The Staph. aureus intoxication is a worldwide problem where several food poisoning outbreaks were reported due to consumption of meat and meat products contaminated with these organisms. Accordingly, the total Staph. aureus count can be taken as index of sanitary. conditions under which the meat and its products are manufactured and handled Potter (2001). And the amount of Staph. aureus in the food depended on several factors including number of contaminated carriers, poor hygiene handling of the food by workers, respiratory secretion ,also transport system Porpino et al (2015), Rahimi - Alang et al. (2011).

According to Egyptian Organization for standardization EOS (1694/ 2005) It has 
been proposed that the minced meat must be free from Staph. Aureus.

Total Coliforms count ( $\mathrm{cfu} / \mathrm{g}$ ) of the examined fresh and frozen minced meat samples:

The prescence of coliforms group has an epidemiological interest as some of the members are pathogenic,

the high incidence of coliform may be due to inadequate cleaning and disinfection, contaminants materials (packaging), bad condition of storage, source of untreated water, or non - compliance with decontamination protocol, lack of precautions or cross contamination as well as the contribution of contamination during the transport of the carcasses in butchers the break of the cold chain or during the mincing process for the minced meat Guemour et al., (2015).

Table (4) show Nearly similar results obtained by Al - kour (2001) who recorded that the mean value of total coliform count was $2.34 \times 10^{3} \pm 0.82 \times 10^{3} \mathrm{cfu} / \mathrm{g}$, Okonko et al ., (2010) who found that the mean value of total coliform count ranged from $1.23 \times 10^{3}$ to $3.42 \times 10^{3} \mathrm{cfu} / \mathrm{g}$, Salem - Amany (2010) who recorded that the mean value of total coliform count was $5.1 \times 10^{3} \mathrm{cfu} / \mathrm{g}$.

However higher findings were obtained by Aslam et al., (2000) who found coliform in all examined samples, Datta et al., (2012) , Erdema - Ayten et al., (2014) who recorded high incidence of coliform $96.6 \%$ with mean value of $4.5 \times 10^{7} \mathrm{cfu} / \mathrm{g}$, and Mohamed (2017) recorded that there were high incidence of coliform $53.6 \%$ in examined samples.

While lower results obtained by $\mathrm{El}$ mali and Yaman (2005) who recorded that the mean value of total coliform count was $2 \times 10$ cfu/g, Bouzid et al., (2015) isolated coliform from $3.89 \%$ of samples, El Kewaiky and Al said (2015) who found that the mean value of total coliform count was $4.57 \pm 4.26 \log 10$ in fresh samples and $3.93 \pm 3.64 \log 10$ in frozen samples, Guemour et al., (2015) isolated coliforms from $3.89 \%$ of samples, Shaltoot et al., (2016) who recorded that the mean value of total coliform count $3.1 \pm 0.1 \log 10$, Zafer (2016) isolated coliform from 9 samples, and Bughti et al., (2017) who recorded that the mean value of total coliform count $3.97 \log _{10}$.

There is a Significant difference between the examined frozen and fresh minced meat samples $(\mathrm{P}>0.05)$.

\section{REFERENCES}

Abdaslam, S. A.; Hassan, M. A.; Kaheel, H. A.; Abobaker, T. M.; Alnourain, T. H.; Hamdan, H. A.; Gokul Shankar, S.; Thambirajah, J. (2014): Isolation of Escherichia coli $\mathrm{O}_{157}$ and other foodborne pathogens from meat products and their susceptibility to differ

Adak, G.K.; Meakins, S.M.; Yip, H.; Lopman, B.A.;O'Brien, S.J. (2005) : Disease risks from foods, England and Wales, 1996- 2000. Emerging Infectious Diseases, 2005 March [cited 2009 August 18]. Available from

http://www.cdc.gov/ncidod/EID/vol 11no03/04-019

Ahmed, A.M. and Ismail, T.H. (2010) : Improvement of the quality and shelf-life of minced beef mixed with soy protein by Sage (Saliva officinal is) .African Journal of Food Science. 4(6): $330-4$.

Al-Kour, M.S.( 2001) : Microbiological status of meat and some meat products in northern Jordan. M.V.Sc. Thesis, Meat Hygiene. Fac. Vet. Med., 
Jordan University of Science and Technology.

Amin-Reham, A.A. (2004) : Microbial evaluation of some meat products. M. V. Sc. Thesis (Meat hygiene), Fac. Vet.Med., Moshtohor, Zagazig University. (BenhaBranch).

Anon (2006) : the community summary report on trendes and sources of zoonoses, zoonotic agent, antimicrobial resistance and food borne outbreaks in the European union in 2005 , the European food safety authority journal , 94(3) : 288 .

Aslam, A. ; Mariam, I. ; Haq, I. and Ali, S. (2000) : Microbiology of Raw Minced Beef. Pakistan Journal of Biological Sciences 3 (8): 13411342.

Attala, O. A. and Kassem, G.M.A. (2011) : Effect of good manufacturing practices (GMP) application on the bacteriological status of butcher $\mathrm{s}$ area in small scale meat processing plant. Global Veterinaria 7(2): 123128.

Azage, M. and Kibret, M. (2017) : The Bacteriological Quality, Safety, and Antibiogram of Salmonella Isolates from Fresh Meat in Retail Shops of Bahir Dar City, EthiopiA. International Journal of Food Science. ID 4317202, 5 pages.

Bouzid,R. ; Guemour,D. ; zidane,k. ; Aggad,H. ; Bendella,A. ; and Saegerman,C. (2015): Hygienic quality of minced meat retailed in wesrern algeria.Journal of Virology and Microbiology.2015 (124808)

Bradeeba, K. and Sivakumaar, P. K. (2013) : "Assessment of microbiological quality of beef, mutton and pork and its environment in retail shops in Chidambaram, Tamil Nadu," International Journal of Plant,
Animal and Environmental Sciences $3: 91-97$.

Bughti, A. ; Abro, S. H. ; Kamboh, A.A. ; Leghari, R. A.; Kumar, C.; and Koondhar S. A (2017) : Bacterial Contamination of Raw Meat and Butchers' Equipment in Retail Shops in Tando-Allahyar, Pakistan. Journal of animal health and production. 5 (3) : $115-128$.

Clarence, S.Y.; Obinna, C.N.; and Shalom, N.C. (2009) : Assessment of bacteriological quality of ready to eat food (Meat pie) in Benin City Metropolis. Nigeria. Afr J Microb Res. 3(6): 390-5.

Cruickshank, R.; Duguid, J.P.; Marmion, B.R. and Swain,R.H.A. (1975) : Medical microbiology , 12 th Ed ., living stone , London , newyork, $812-825$

Datta,S.; Akter, A.; Shah, I.G.; Fatema, K.;Islam, T.H.; Bandyopadhyay, A.; Khan, Z.U.M. ; and Biswas, D. (2012) : Microbiological Quality Assessment of Raw Meat and Meat Products and Antibiotic Susceptibility of Isolated Staphylococcus aureus. J. Agric. Food.

Downes, F.P. and Ito, K. (2001) : Compendium of methods for the microbiological examination of foods. 4th ed., American Public Health Association Press, Washington, D.C., USA.

Egyptian standard specification (ESS 1694 / 2005) (2005): Egyptian standards specification for minced meat. Egyptian Organization for Standardization and Quality Control.

Elmali, M.; and Yaman, H. (2005) : Microbiological Quality of Raw Meat Balls: Produced and Sold in the 
Eastern of Turkey. Turkey Pakistan Journal of Nutrition. 4 (4): 197-201.

Erdem, B.; Ercis, S. ; Hascelik, G. ; Gur, D. ; and Aysev, A. D. (2005) : Antimicrobial resistance of Salmonella enterica group C strains isolated from humans in Turkey, 2000-2002. International Journal of Antimicrobial Agents. $26: 33-37$.

Erdem-Ayten, k.; Saglam, D.; Ozer, D.; and Ozcelik, E. (2014) : Microbiological Quality of Minced Meat Samples Marketed in Istanbul YYU Veteriner Fakultesi Dergisi., 25: 67 -70.

EL-Kewaiky, I.A.; and AL-Said, A.A. (2015) : Microbial and Chemical quality of retailed minced meats . Assuit. Vet. Med. J. 61(147): 95-105.

El-Taher-Amna, M (2009): Impact of temperature abuse on safety of food offered in an University Student Restaurant. M.V.Sc. Thesis, Meat Hygiene, Fac. of Vet. Med. Moshtohor, Benha Univ.

Food and Drug Administration (FDA) (2001): Foodborne illness, what consumer need to know. USDA Food Saftey and Inspection Service.

Goja, A.M. ; Ahmed, T.A.A. ; Saeed , S.A.M. ; and Dirar, H.A. (2013) : Isolation and Identification of Staphylococcus spp. in Fresh Beef Pakistan Journal of Nutrition 12 (2): 114-120.

Guemour, B.R.; Zidane, D.; Aggad, K.; Bendella, H. and Saegerman (2015) : hygienic quality of minced meat retailed in western Algeria. J. of virology and microbiology . vol. 2015. , Article ID 124808 .

Gwida,M. ; Hotzel, H. ; Geue, L. ; and Tomas, H. (2014) : occurance of enterobacteriaceae in raw meat and in human samples from Egyptian retail sellers . international scholar research , vol. 2014, Article ID 565671,6 pages.

Hannan, A.; Sidrah, S.; Chaudhary, S.; Barkaat, M. and Arshad, M. U. (2008) : Antibacterial activity of Nigella Sativa against clinical isolates of Methicillinresistant Staphylococcus aureus. J. of Ayub Medical College, Abbottabad, 20.

Hassanein, R. ; Hassan Ali, S.F.; Abd EL Malek , A.M.; Mohamed , M.A. and Elsayh, K.I. (2011) : Detection and identification of salmonella species in minced beef and chicken meats by using multiplex PCR in Assuit city . Veterinary World. 4(1) : 5-11

Home and Garden Information Center (HGIC) (2000): Food borne illness: Prevention Strategies www document. Http://www. Hgic. Clemson. Edu.

International Organization of Standardization "ISO" (2003): No. 6887-2 Microbiology of food and animal feeding stuffs - Preparation of test samples, initial suspension and decimal dilutions for microbiological examination -- Part 2: Specific rules for the preparation of meat and meat products.

International Organization for Standardization (ISO) (2004): No.11291-1. Microbiology of food and animal feeding stuffs - Horizontal methods for detection and enumeration of Enterobacteriaceae part2 : colony count. Method.

Iraha,I.R.; ugbo,E.C.; Ilang,D.C.; Oji,A.E.; and Ayogu,T.E. (2011) : Bacteria contamination of raw meat sold in Abakaliki, Ebonyi state Nigeria. Journal of public health and Epidemiology 3(2) : 49-53 .

Javed, A. (2016) : Food Borne Health Issues and Their Relevance to Pakistani 
Society. American Scient. Res. J. Engin. Technol. Sci. (ASRJETS). 26(4): 235-251.

Lamada-Hanan, M.; Nassif-Marionette, Z.; Eleiwa-Nesreen, Z. (2012) : Microbiological evaluation of some chicken meat and meat products. Egypt. J. Agric. Res., 90(1):279-293. Maarouf, A.A. and Nassif-Marionette, Z. (2008) : Bacteriological studies on frozen cow meat and some meat products at Benha city. J. Egypt. Vet. Med. Assoc., 68(1):129-141.

Naka, M. ;shimizu, A. ;kawano, J. ; and igimi, S. (2006): prevalence and characterization of Staphylococcus Aureus in retail raw minced meat. Jpn. J. food microbial. 23(4) : 217222.

Naomi, B. and Avraham, R.. (2000) : Staphylococcal enterotoxins Int. J. Food Microbiol., 61: 1-10.

Mohamed, A. D. (2017) : the microbiological study of minced meat in some markets in Alexandria with reference to Es. coli O157:H7. International J. of research - granthaalayah.. 5 (9) : $26-35$.

Mohammed, N.I. and Alwan, m.j. (2017) : Isolation and Identification of Staphylococcus aureus strain from fresh and frozen meat in karbala province. International journal of science and nature. 8 (3) : 704 - 709.

Morshdy Alaa El-Deen, M.; El-Atabany Adel, L.; Hussein Mohamed, A.; and Nasser Mohammad,A.( 2013) : detection of entertoxigenic staphylococcus aureus in some meat products. Assiut. Vet. Med.J.,59:100106.

Normanno, G.; Firinu, A.; Virgimo, S.; Mula,G.; Dambrosio, A.; Poggiu, A.; Decastelli, L.; Mioni, R.; Scuota, S.; Bolzoni, G.; Digiannatale, E.;
Salinetti, A.P.; LA Salandra, G.; Bartoli, M.; Zuccon, F.; Pirino, T.; Sias, S.; Parisi, A.; Quaglia, N.C. and Celano, G.V. (2005): Coagulase positive Staphylococci and Staphylococcus aureus in food products marketed in Italy. Int. J. Food Microbiol.Jan.15; 98(1):73-79.

Okonko ,I.O.; Nkang, A.O. ; Udeze, A.O.; Babalola, T.A. ; Mejeha, O.K.; and Fajobi, E.A. (2010) : assessment of microbiological quality of fresh meat sold in Calabar metropolis , Nigeria . EJEAFChe, 9 (1) : [89-100].

Olaoye, O. A. (2011) : "Meat: an overview of its composition, biochemical changes and associated microbial agents," International Food Research Journal . 18. ( 3) : 877-885.

Omemu ,A.M.; and Bankole, M.O. (2005) : Ready-to-eat (RTE) vegetable salad: effect of washing and storage temperature on the microbial quality and shel-life. In: the Book of Abstract of the 29th Annual Conference \& General Meeting(Abeokuta 2005) on Microbe Potter, N. (2001): Food Science. 4th Ed., The AVI publishing Co., Inc., New York, USA.

Porpino, G.; Parente, J. and Wansink, B. (2015) : Food waste paradox: antecedents of food disposal in low income households. International journal of consumer studies, 39(6), 619-629.

Ragab, W.S.; Ehsan A.B. Hassan ; AlGeddawy M.A. and Albie, A.A. (2016) : Bacteriological Quality of some Meat Products in the Egyptian Retail Markets Assiut J. Agric. Sci., 47(6-2) : (422-429).

Rahimi-Alang, S.; Cheraghali, F.; Yazarlou, S.;Amini A.; Shakeri, F.; and Ghaemi, E. (2011) : Frequency of 
methicillin resistant Staphylococcus aureus in health care. Zahedan J Res Med Sci. 13:17-22.

Rajic, A.; Waddell, L.A.; Sargeant, J.M.; Read, S.J.; Farber, M.J.; Firth, A. and Chambers. (2007) : An overview of microbial food safety programs in beef, pork, and poultry from farm to processing in Canada. J. Food Protect., 70: 1286-1294.

Rao, V.A.; Thulasi, G.; and Ruban, S.W. (2009) : Meat quality characteristics of non-descript buffalos as affected by age and sex. World Applied Science Journal.1058-65.

Salek, M. (2000): Microbial control of cooked meat foods and lettuces served in Beheshti Medical Sciences University restaurants. Ph.D. Thesis; (154): 63-9.

Salem-Amany, M.; Amin-Reham, A.; AfifiGehan, S.A. (2010) : Studies on Antimicrobial and Antioxidant Efficiency of Some Essential Oils in Minced Beef. J. American Sci., 6: 691-700.

Schelin , J. ; Carlquist, N.W. ; Cohn , M.T. ; Lindquist, R. ; Barker, G. ; and Radstorm, P. (2011) : The formation of staphylococcal aureus enterotoxins in the food environments and advanced in risk assessment virulence , 2(6) : $580-$ 592.

Shaltout , F.A.; Salem, A.M.; Khater, A.M.; and Lela, R.A. (2016) : Studies on bacteriological Profile of some meat products. Benha vet. Med. J., 31 (1) :43-49.

Siriken, B. (2004) : the microbiological quality of ground beef in aydin and afyon provinces, turkey, Revue de medicine veterinaire 155 (12) : 632 636.
Stewart, C.M. ; Cole, M.B. ; and Schaffner, D.W. (2005) : Managing the risk of staphylococcal food poisoning from cream- filled backed goods to meet afood safety objectives . J. Food prot., 7(66) : 1310-1315.

Tachbele, E.; Erku, W.; Gebre-Michael, T.; and Ashenafi, M. (2006) : Cockroach associated food-borne bacterial pathogens from some hospitals and restaurants in Addis Ababa, Ethiopia: Distribution and antibiograms. $\mathbf{J}$ Rural Trop Public Health. 5: 34-41.

Taha, N. E.A. (2002): Zoonotic importance of enteropathogenic Escherichia coli (EPEC). Ph. D. Thesis (Meat hygiene), Fae. Vet. Med., Zagazig University.

Tassew,H.; Abdissa,A.; Beyene,G.; and Gebre-Selassie,S. (2010) : Microbial flora and food borne pathogenes on minced meat and their susceptibility to antimicrobial agents, Ethiopian journal of health science 20(3) .

Tarabees, R.Z.; Hassanin, Z.H.; and El Bagoury, A.M. (2015): Polymerase chain reaction (PCR) : An alternative rapid method for detection of some Microbial contamination of meat products. Alexandria J. of vet. Sci. 45:91-98.

U.S. Department of Health and Human Services Food and Drug Administration Center for Food Safety and Applied Nutrition (USFDA) (2004): S.aureus, Bad Bug Book. Food-home pathogenic Microorganisms and Natural Toxins Handbook. U.S. Department of Health Chapter accessed.

Velzen, E.U.T. and Linnemann, A.R. (2008): Modified Atmosphere Packaging of Fresh Meats - Sudden Partial Adaptation Caused an Increase in Sustainability of Dutch Supply 
Chains of Fresh Meats. Packaging and Technological Science, 21: 3746.

Zafar, A.; Ahmed,E.; Wajiha,H.; and Khan,A.B. (2016) : microbiological evaluation of raw meat products available in local markets of Karachi , pakistain . proceeding of pakistain academy of sciences 53 (2) : 103 109 .

Zweifel, C.; Fisher, R. and Stephan, R. (2008) : Microbiological contamination of pig and cattle carcasses in different smale - scale Swiss abattoirs. Meat science 78 (3) : $225-231$. 